\title{
Factors Enhancing Member Commitment to Trade Unions in the Hospitality Industry in Zimbabwe
}

\author{
Farai Ncube ${ }^{1}$ \\ ${ }^{1}$ Department of Human Resource Management, Midlands State University, Box 9055 Gweru, Zimbabwe \\ Correspondence: Farai Ncube, Department of Human Resource Management, Midlands State University, Box 9055 \\ Gweru, Zimbabwe. ORCID ID 0000-0002-8749-5055. Tel: 263-778-097-654. E-mail: fncube@staff.msu.ac.zw
}

Received: June 16, 2020 Accepted: June 25, 2020 Online Published: June 29, 2020

doi:10.5430/jbar.v9n1p33 URL: https://doi.org/10.5430/jbar.v9n1p33

\begin{abstract}
Trade unions in the hospitality industry have long served an important and vital role, acting as the vanguard to protect the worker's rights and their financial livelihood, hence stressing their importance. Their future however remains hanging in balance as they continue to face an array of challenges and changes threatening their existence. In this paper the researcher attempt to respond to the question on, "why would individuals choose to be loyal and committed to trade unions?' Finding through a 5 point likert scale administered on 227 members belonging to the Zimbabwe Catering and Hotel workers Union (ZCHWU) and interviews conducted with 18 union officials reveals that commitment is determined by the ability of the union to satisfy member expectations. Findings reveals that member commitment manifest itself through individual's strong desire to remain a member of the union; willingness to exert high effort on behalf of the union as well as belief in the union goals and leadership. The study concludes that the unions' ability to satisfy and meet its member's expectation contributes to trade union commitment.
\end{abstract}

Keywrds: trade union, employee commitment, hospitality industry, Zimbabwe

\section{Introduction}

The question on factors that enhance employee to commit to trade unions is best tackled by Kollmeyer (2013) who documents the behavioural and attitudinal differences among workers shaping their propensities to join trade unions and harness commitment. It is not a secret that trade unions have long served an important and vital role in the industry, acting as the vanguard to protect the worker's rights and their financial livelihood, hence stressing their importance. It is imperative that trade unions as voluntary institution convince their members of its worth as a bargaining institution. With members convinced to fully participate in unionism, unions may still remain afloat. This therefore places the significance of member commitment. Globally union leaders express an interest in the members' commitment to the union because their ability to bargain collectively from a position of strength depends heavily on the loyalty of their membership. However one cannot talk about union commitment by ignoring union participation as the two go hand in-glove. Union participation in general covers the behavioural involvement of union members in the operation of their union. Tripiti and Ginni (2015) points out to the involvement of members in collective action and other union related activities which are closely related to effective working of the union. They go on to explain that behavioural study on union members' participation fall into two categories, first, the structural determinants and second, the beliefs, attitudes, and perceptions of union members. The study therefore utilises factors adopted from Herzberg (1959) two factor theories. Both hygiene and motivational factors are considered and applied to determine the factors leading to member commitment to trade unions.

\section{Literature Review}

Originally developed in the context of commitment to the employer, research on trade union commitment gathered momentum around the 1980s. Major academic interest in this subject began with the Gordon et al. (1980) pioneering use of factor analysis to develop four specific dimensions of union commitment. Each dimension reflects either a specific underlying worker attachment to the union or implications for membership behaviours. The authors identify belief in the unions, union loyalty, and willingness to work for the union and responsibility to union as four key dimensions of union commitment. These are crucial determinants of member commitment. Several scholars who discussed on trade union commitment focussed on different dimensions. It is clear to point out that joining a union and committing to a union present two separate faces of the same coin. Employees may join unions but may not be 
fully committed to the union given that commitment is an individual choice. Burry and McDaniels (2018) observe that workers may be part of a union but lacking full commitment to the union citing the case of young workers. . this proves that employees make the choice to join unions based on the perceived benefit of membership.

Goals of protecting and enhancing employees' living standards motivate workers to join trade unions and stay in the union (Gall \& Fiorito, 2016). Gaining power is often an implicit goal for unions and act as a motivator for members to join unions (Lévesque \& Murray, 2013). Members can join a trade union and stay within and participate in union activity if the trade union is able to secure benefits for its membership at large (Gall \& Fiorito, 2016). Dufour-Poirier and Laroche (2015) state that the ability of unions to properly market themselves, through proper education of the perceived union benefits, training of union workers, opportunities for growth, proper leadership and governance remains key towards membership attraction. Trade unions are there to enhance the economic well-being of workers in an organisation. Since time immemorial, trade unions have been acting as political protagonists of minimum wage regulations (Seeliger, 2018).

Union commitment represents one of the ways in which members are motivated to stay in unions. One method of measuring union commitment remains the willingness by members to display effort on behalf of the union (Angrave, Charlwood, \& Greenwood, 2017). A good working association in a good industrial relations climate is viewed as another reason which motivates people to stay in unions (Gall \& Fiorito, 2016). More so, Gall and Fiorito (2016) conclude that resources and conditions available for workers is a remedy to harness commitment. Another identified motivator to join and stay in unions has been the need by workers to protect their interests (Angrave, Charlwood, \& Greenwood, 2017). Green and Auer (2013) note that perceived union instrumentality represents another reason why workers are committed to stay in unions. This construct represents members' perception of the union's ability to improve workers' welfare with regard to both the traditional (e.g., wages) and non-traditional (e.g., job satisfaction) working conditions. Avgar, Boris, Bruno and Chung (2018) say the ability to handle workers concerns, having in place proper grievance handling mechanisms and procedure in place compels employees to participate in trade unionism. The impetus for good working conditions and the desire to have a good life in any economic context induce workers to join trade unions (Manky, 2018). Alshimeri, et al (2017) thus suggest that working condition cover the work station design and other related facilities as well as equipment within a workplace.

Acayan, Cua, Te and Teng-Calleja (2015) say, traditionally, trade unions have been instrumental in voicing out the opinions, grievances, and demands of workers in organizations and societies. The need for a well improved working environment allowed unions to attract membership (Leschke \& Vandaele, 2018). The need to balance power between management and workers pushed workers towards collectivism (Gall \& Fiorita, 2016). Grievances between and among key stakeholders at the workplace mainly employer employees pushed workers to collectivise (Angrave, Charlowood, \& Greenwood, 2015). Unbearable working conditions gave workers an impetus to join trade unions (Manky, 2018). Through collective bargaining agreements and strike movements, unions have successfully provided workers with the means to secure better working conditions and improved standards of living as noted by Acayan, et al. (2015).

Members also join unions because they hope for perceived benefits. Union instrumentality represents the member's perception of the union's ability to improve the workers' welfare with regard to both the traditional (e.g. wages) and non-traditional (e.g., job satisfaction) conditions of work (Green \& Auer, 2013). Anyango, Obange, Abeka, Odiek, Odera, and Ajugi (2013) also say that when workers are ill-treated, underpaid and face unbearable condition unionism becomes a viable option. A union that ensure that effective working conditions are maintained easily harness commitment. Bryson and Freeman (2013), points out that workers' instrumental basis for union membership and their attitudes in favour of unions are inversely correlated with their working conditions. Bryson and Freeman (2012) and Okechuku (2016) posit that employee perception on their perceived working condition can be reason enough for them to seek union representation. Culture plays a crucial role in determining whether employees are committed or not to unions. This is supported by Crounch (2017) who points out that, most research on union membership has concluded that workers are not motivated to join by expectation of calculable individual gains, but by seeing themselves as part of a general culture, of which union membership is a part.

\subsection{Theoretical Framework}

The study utilise Herzberg's (1959 in Alshimeri et al., 2017) Two-Factor theory. Herzberg, Mausner and Snyderman (1959) published the Two-Factor theory of work motivation, greatly influenced by Maslow's work from his Hierarchy of Needs Theory. Alshimeri et al., (2017) point out that the theory is a two-dimensional paradigm of factors influencing people's attitudes towards work. In this respect, there are some attitudes that if adopted by workers they may either lead to motivation and subsequently commitment to trade unions or may lead to 
de-motivation resulting in limited or no commitment to unions. In principle, the main hypothesis of Herzberg's theory was that certain factors lead to positive attitudes towards work while others lead to negative attitudes. Alshimeri et al., (2017) identified that the first category is associated with the need for growth or self-actualisation, and these were termed motivation factors. These motivational factors include achievement, recognition; work itself, responsibility, advancement and the possibility for growth. These are very crucial and for the purpose this study, are used as factors that, when satisfied, can influence members to commit to their unions. Failure to satisfy them may be a clear indicator as to why individuals may not join or commit to trade unions. Herzberg (1959 in Alshimeri et al., 2017) identified the second category of factors related to a need to avoid unpleasantness, termed hygiene factors. These factors include company policies and administration; relationship with supervisors, interpersonal relations, working conditions and salary. Again these have to be managed by unions to ensure membership commitment. Herzberg (1959 in Alshimeri et al., 2017) points out to the differences between motivation and hygiene factors, or intrinsic and extrinsic factors. Herzberg described motivation factors as intrinsic to the job and hygiene factors as extrinsic to the job. Alshimeri et al., (2017) concludes that, motivational factors operate to only increase and improve job satisfaction; whereas hygiene factors work to reduce job dissatisfaction.

\section{Methods}

In this study we applied a mixed method approach, utilising an explanatory design using sequential phases (quantitative-qualitative). Mixed method approaches provide different pictures and allows flexibility to intersect data (Clark and Ivankova, 2016; Barker, 2016). The reseacher adopted a single case study (of the hospitality industry), with embedded units (three groups of hotels). Quantitatively 227 members of the Zimbabwe Catering and Hotel Workers Union (ZCHWU) drawn from three hotel groups participated in the study, by filling a 5 point likert scale over a period of 2 month. The analysis of the findings informed the crafting of qualitative questions which guided the interviews and focus group discussions with 18 participants drawn from fulltime Union Officials and Management Representatives. The focus group discussions and the interviews were undertaken between August and November 2019. Data was collected through the use of both primary and secondary sources of data. The research was undertaken in two phases. The first phase was to understand employee views of trade unions through a quantitative approach (a questionnaire with closed questions and numerically rated items). The quantitative data obtained from the dominant hotel groups was analysed to form the basis for a qualitative research, (through the use of semi structured interview questions and focus group discussions). Data analysis was guided by explanatory sequential mixed method design. The quantitative data obtained was analysed through the use of the Statistical Package for the Social Sciences (SPSS) version 25. We however combined the results as presented below.

\section{Results}

This section details the results obtained from the questionnaire that was distributed to 227 union members. Findings from the qualitative study are also presented concurrently. The following are the factors that were pointed out by respondents adopted and modified from Herzberg 1959's two factor theory.

Table 1. To improve working conditions

\begin{tabular}{llllll}
\hline & Frequency & Percent & Valid Percent & Cumulative Percent \\
\hline Valid & Strongly agree & 86 & 37.9 & 37.9 & 37.9 \\
& Agree & 48 & 21.1 & 21.1 & 59.0 \\
& Neutral & 26.0 & 26.0 & 85.0 \\
& Disagree & 11.0 & 11.0 & 96.0 \\
& Strongly disagree & 9 & 4.0 & 4.0 & 100.0 \\
& Total & 227 & 100.0 & 100.0 & \\
\hline
\end{tabular}

Source: SPSS version 25.

Table 1 above clearly shows how respondents felt regarding the union's ability to improve working conditions in relation to trade union commitment. Of the respondents under study, 86 (37.9\%) strongly agree, $48(21.1 \%), 59(26 \%)$ were neutral to the view as stated above, $25(11 \%)$ disagree and $9(4 \%)$ strongly disagree. From the interviews conducted union official pointed that one the reason why employees get committed to join the union in the hotel 
industry is the ability to ensure good working conditions. One union official explained that some hotels were taking advantage of casual and contract employees forcing them to work long hours and night shifts, while others were denied proper safety within their work stations. The other union official cited low wages and poor incentives as one other condition the union was fighting for. Managerial respondents pointed out that ZCTWU was on record fighting for a fair minimum wage through the National employment Council (NEC) negotiations. Respondents also cited sighted safety in the kitchens, gardens, bars and restaurants as key for effective service delivery. With the union able to satisfy these members would commit and participate in the union business.

From the above findings we argue that the union/s ability to improve the working conditions of its members compels them to commit to the union. It's an un-debatable fact that workers spend the majority of their time and with bad working conditions they detach themselves. With the union able to influence a good working environment and condition workers easily become committed to both their work and the union making it possible to offer an exceptional service delivery. While good working conditions increase commitment unbearable working conditions give workers an impetus to join trade unions (Manky, 2018). However through participating in collective bargaining and ensuring collective agreements to secure better working conditions and improved standards of living is achieved workers easily get committed to the trade unions as noted by Acayan et al., (2015). When workers look at their working conditions and consider it favourable they adopt positive attitudes, to join, participate and support the union.

Table 2. To ensure personal advancement

\begin{tabular}{llllll}
\hline & Frequency & Percent & Valid Percent & Cumulative Percent \\
\hline Valid & Strongly agree & 83 & 36.6 & 36.6 & 36.6 \\
& Agree & 62 & 27.3 & 27.3 & 63.9 \\
& Neutral & 18.5 & 18.5 & 82.4 \\
& Disagree & 12.8 & 12.8 & 95.2 \\
& Strongly disagree & 11 & 4.8 & 4.8 & 100.0 \\
& Total & $\mathbf{2 2 7}$ & $\mathbf{1 0 0 . 0}$ & $\mathbf{1 0 0 . 0}$ & \\
\hline
\end{tabular}

Source: SPSS version 25.

Table 2 shows how participants responded to the issues of the union's ability to ensure personal advancement in relation to trade union commitment. Of the respondents under study, 83 (36.6\%) strongly agree, 62 (27.3\%), 42 $(18.5 \%)$ were neutral to the view as stated above, $29(12.8 \%)$ disagree and $11(4.8 \%)$ strongly disagree. The same was pointed through a focus group discussion that workers valued personal growth more than anything. A union official pointed out that; unions play a pivotal role given that personal growth focus on an individual and at times such individuals will not have a bargaining power hence the unions enforce policies at NEC level as well as at establishment level....

Virtually respondents identified that the hotel industry was developing and changing with new technology and other software packages like self check inn facilities, accounting packages, guest feedback programs that challenged workers to advance academically and professionally through either going to universities or attending conferences and trainings. With unions pushing for self advancement members find it easy to participate and support fully the union. However some managerial respondents felt that the union had a little role in personal development beyond encouraging members to progress as this was at the discretion of the employer. One manager had this to say; ....yes $I$ agree unions have a role to play but the honours lies with management. After all there is a mutual benefit. We want good service to be given and we want customers to be happy so that we meet our targets, and get the average rooms' rates as well as the revenues per cover...

Findings show that employees to some extent join trade unions for the reasons of advancing their career and other employment opportunities. The ability of a union to guarantee this may result in trade union commitment, as it creates a positive perception on the union leadership effort. In general most people are worried by their personal growth at the workplace. A union that advocate for continued growth through training and development stands a chance to recruit, maintain and have members participate in union business. We argue that this can be enhanced by both unions and management in collective bargaining if it's made part of the organisational culture which embraces all employees. The same argument is advanced by Crounch (2017) who points out that, most research on union 
membership commitment has concluded that workers are not only motivated to join by expectation of calculable individual gains, but by seeing themselves as part of a general culture, of which union membership is a part. Bearing in mind that employees will always commit to unions because of the need to ensure proper representations from trade unions remains crucial as pointed out by Bryson \& Freeman (2012).

Table 3. To guarantee personal growth

\begin{tabular}{llllll}
\hline & Frequency & Percent & Valid Percent & Cumulative Percent \\
\hline Valid & Strongly agree & 92 & 40.5 & 40.5 & 40.5 \\
& Agree & 33 & 14.5 & 14.5 & 55.1 \\
& Neutral & 28.2 & 28.2 & 83.3 \\
& Disagree & 34 & 13.2 & 13.2 & 96.5 \\
& Strongly disagree & 8 & 3.5 & 3.5 & 100.0 \\
& Total & $\mathbf{2 2 7}$ & $\mathbf{1 0 0 . 0}$ & $\mathbf{1 0 0 . 0}$ & \\
\hline
\end{tabular}

Source: SPSS version 25

The general commitment of individual union members is determined by the ability of the union to guarantee personal growth. Table 3 indicates how participants responded to having unions guarantee personal growth in relation to trade union commitment. Of the respondents under study, 92 (40.5\%) strongly agree, $33(14.5 \%), 64(28.2 \%)$ were neutral to the view as stated above, $30(13.2 \%)$ disagree and $8(3.5 \%)$ strongly disagree. Findings concur that employees have the desire to grow in their employment post hence they join trade unions to ensure that their desires are being achieved. Thus, the ability of the trade union to satisfy them in this area can generally lead to trade union commitment. The above findings collaborate well with the views of Burry and McDonalds (2018) that the majority of workers are worried by their personal growth at the workplace. Any institution that fosters that compels workers to be fully committed. A wise union thus ensure that its members are able to grow.

The interviews conducted mainly with management respondents suggested that personal growth had a dual benefit to both the hotels and to trade union. Individuals are more committed to the organisation that employs them and ZCHWU as their main representative benefited from this mutuality. Influencing personal growth therefore becomes an antidote of union commitment, another interesting observation by Burry and McDaniels (2018) is that, young workers appear to want trade unions that reflect their personal views and ambitions. This is what is crucial and can act as a factor compelling individuals to commit to the union.

Table 4. To influence salary increase

\begin{tabular}{llllll}
\hline & Frequency & Percent & Valid Percent & Cumulative Percent \\
\hline Valid & Strongly agree & 113 & 49.8 & 49.8 & 49.8 \\
& Agree & 57 & 25.1 & 25.1 & 74.9 \\
& Neutral & 18.9 & 18.9 & 93.8 \\
& Disagree & 73 & 3.1 & 3.1 & 96.9 \\
& Strongly disagree & 7 & 3.1 & 3.1 & 100.0 \\
& Total & $\mathbf{2 2 7}$ & $\mathbf{1 0 0 . 0}$ & $\mathbf{1 0 0 . 0}$ & \\
\hline
\end{tabular}

Source: SPSS version 25

Salary was identified as a crucial factor leading to member commitment to ZCHWU. Virtually all respondents including management participants pointed out that a union's ability to satisfy member expectations on salaries and other benefits was an antidote to commitment. Table 4 show results on unions influencing salary increase in relation to trade union commitment. Of the respondents under study, $113(49.8 \%)$ strongly agree, 57 (25.1\%), $43(18.9 \%)$ were neutral to the view as stated above, 7 (3.1\%) disagree and $7(3.1 \%)$ strongly disagree. On average $74.9 \%$ of the 
respondents agree to the view that employee join trade unions primarily because they need salaries that are in line with the efforts as well as the sacrifices at work. Results concur with the view that employees at work are satisfied with the reward systems that are offered by the company hence joining the trade unions or committed to them will help them in bargain salary increases and in the process results in trade union revitalization (Burry and McDaniels, 2018)

Just like the majority of respondents in Table 5 above we argue that salary is and remains one of the reasons why people go for work. The trade union's ability to satisfy that need will compel people not only to join and become members but fully commit to the union since the union will have a direct benefit of satisfying one of their fundamental needs. While the percentage of those neural is high, which may explain that other members do not consider money or are not aware of the level at which the union can influence pay. More can still be done by the union around this area to ensure union commitment. Salary enhances the economic well-being of workers in an organisation and ability of any union to satisfy this guarantees commitment. The same is advanced by Seeliger (2018) who points out that since time immemorial, trade unions have been acting as political protagonists of minimum wage regulations (Seeliger, 2018). Hotels that pay more in most cases gets the best and while the ZCHWU dominates the industry and is responsible for collective bargaining with employers, the union also empowers through basic education shop stewards to negotiate for local incentives beyond the guaranteed minimum wages. From the findings the minimum offered out of the NEC negotiations was RTGS 1900 (inclusive of transport allowance and housing allowance) amounting to USD $\$ 6500$. With such low rates the ZCHWU has been fighting with employers which have seen a number of hotels offering the Cost Of Living Adjustment (COLA) to caution members from hyper inflation sweeping across the country. So the union has been the pillar of strength in Collective Bargaining. Given that the hotel industry generates foreign currency the unions have pushed for a USD \$ payments. Not only union members have benefited from this arrangement. Even managers have also benefited out the union efforts hence a plus on unions.

Table 5. To ensure good supervision

\begin{tabular}{llllll}
\hline & Frequency & Percent & Valid Percent & Cumulative Percent \\
\hline Valid & Strongly agree & 94 & 41.4 & 41.4 & 41.4 \\
& Agree & 69 & 30.4 & 30.4 & 71.8 \\
& Neutral & 16.3 & 16.3 & 88.1 \\
& Disagree & 77 & 7.9 & 96.0 \\
& Strongly disagree & 9 & 4.0 & 4.0 & 100.0 \\
& Total & $\mathbf{2 2 7}$ & $\mathbf{1 0 0 . 0}$ & $\mathbf{1 0 0 . 0}$ & \\
\hline
\end{tabular}

Source: SPSS version 25

Table 5 above depicts how the respondents reacted to unions ensuring good supervision in relation to trade union commitment. Of the respondents, $94(41.4 \%)$ strongly agree, $69(30.4 \%), 37(16.3 \%)$ were neutral to the view as stated above, $18(7.9 \%)$ disagree and $9(4.0 \%)$ strongly disagree. This entails that $71.8 \%$ on average were in agreement with that fact that employee committed to trade union was to harness good supervision. Findings from several interviews unearthed that workers were worried through the manner they were being supervised by their leaders within their sections. One union official pointed out that, "we have received several cases of harassment of workers, in the restaurants and bars, by their supervisors, ranging from intimidation, dehumanisation and at times sexual harassment.' Several union officials highlighted that they were involved in designing a basic education program to all hotel employees on their basic rights, as per the NEC regulations. This targeted contract and permanent workers, as well as part-timers and students on attachment, who at times are taken advantage of as a source of cheap labour. This has increased the visibility of the union.

Trade unions ability to ensure line managers work well with workers grantee union commitment. The findings buttress the fact that in most cases employees leave managers and not their work as supported by Ncube (2017). Unions thus have a duty to ensure that supervisors work well with their members, which can be a recipe for enhancing membership participation in union business and commitment. Good supervision act as a platform to enhance good working conditions. With bad supervisors the workplace becomes a battle field. The union ability to 
guarantee good leadership and supervision leads to an enhanced worker commitment to the union. The need for a well improved working environment allows unions to attract membership as pointed out by Leschke \& Vandaele (2018). The same is indirectly pointed by Gall and Fiorita (2016) who also point out that the need to balance power between supervisors and workers pushed workers towards collectivism (Gall \& Fiorita, 2016).

Table 6. To improve interpersonal relations

\begin{tabular}{llllll}
\hline & Frequency & Percent & Valid Percent & Cumulative Percent \\
\hline Valid & Strongly agree & 92 & 40.5 & 40.5 & 40.5 \\
& Agree & 61 & 26.9 & 26.9 & 67.4 \\
& Neutral & 22.0 & 22.0 & 89.4 \\
& Disagree & 14 & 6.2 & 6.2 & 95.6 \\
& Strongly disagree & 10 & 4.4 & 4.4 & 100.0 \\
& Total & $\mathbf{2 2 7}$ & $\mathbf{1 0 0 . 0}$ & $\mathbf{1 0 0 . 0}$ & \\
\hline
\end{tabular}

Source: SPSS version 25

Table 6 shows on how the respondents, reacted to unions improving interpersonal relations in relation to trade union commitment. Of the respondents, $92(40.5 \%)$ strongly agree, $61(26.9 \%), 50(22.0 \%)$ were neutral to the view as stated above, $14(6.2 \%)$ disagree and $10(4.4 \%)$ strongly disagree. Findings also show that employees are committed in join trade unions due to the fact that they improve interpersonal relations that exist between the employer and the employee or among members themselves. Thus, the ability for a union to ensure that such an environment exists guarantees union membership participation leading to commitment. The need to balance power between supervisors and workers pushed workers towards collectivism and can guarantee worker commitment to their union as pointed out by (Gall \& Fiorita, 2016). Union instrumentality represents the member's perception of the union's ability to improve the workers' welfare with regard to both the traditional (e.g. wages) and non-traditional (e.g., job satisfaction) conditions of work (Green \& Auer, 2013).

Table 7. To influence company policies

\begin{tabular}{llllll}
\hline & Frequency & Percent & Valid Percent & Cumulative Percent \\
\hline Valid & Strongly agree & 101 & 44.5 & 44.5 & 44.5 \\
& Agree & 65 & 28.6 & 28.6 & 73.1 \\
& Neutral & 28 & 12.3 & 12.3 & 85.5 \\
Disagree & 21 & 9.3 & 9.3 & 94.7 \\
& Strongly disagree & 12 & 5.3 & 5.3 & 100.0 \\
& Total & $\mathbf{2 2 7}$ & $\mathbf{1 0 0 . 0}$ & $\mathbf{1 0 0 . 0}$ & \\
\hline
\end{tabular}

Source: SPSS version 25

The ability of a trade union to participate in collective bargaining and be able to achieve influence in all company policies and procedures reflects the significance of joining, maintaining and participating in union business. Table 7 above shows results on the ability of a union to influence members to participate in determining company policies. Of the respondents, $101(44.5 \%)$ strongly agree, 65 (28.6\%), 28 (12.3\%) were neutral to the view as stated above, 21 $(9.3 \%)$ disagree and $12(5.3 \%)$ strongly disagree. On average $37 \%$ were in agreement to the view that employee commitment to joining trade unions is for the ability to influence company policies. Focus group discussion results with the respondents highlighted that ZCHWU was on record on insisting that they are involved in crafting key company policies. A senior union official pointed out that; 'as a union we are trained by seasoned labour specialist from our labour centre the Zimbabwean Congress of Trade Union (ZCTU). As such we are more knowledgeable and understand better. We encourage all our workers committee members in these groups to consult before they append a signature to any document'. Management representatives also pointed out that in order to maintain harmony in the 
industry they consult and involve the union through the workers committees.

Some of the policies that are installed or gazetted by most organization are there for the benefit of shareholders at the expense of the employees. A heightened sense of commitment can be achieved when trade unions are able to convince members to participate in formal decision-making and/or policy-making processes, it also requires them to actively participate 'in carrying out the work of the union, such as membership mobilization (Gall \& Fiorito, 2012). Avgar et al., (2018) say the ability to handle workers concerns, having in place proper grievance handling mechanisms and procedure in place compels employees to participate in trade unionism. The impetus for good working conditions and the desire to have a good life in any economic context induce workers to join trade unions (Manky, 2018). Alshimeri, et al (2017) thus suggest that working condition cover the work station design and other related facilities as well as equipment within a workplace. The ability of the union to satisfy these guarantee member commitment to unions.

Table 8. To ensure effective representation

\begin{tabular}{llllll}
\hline & Frequency & Percent & Valid Percent & Cumulative Percent \\
\hline Valid & Strongly agree & 104 & 45.8 & 45.8 & 45.8 \\
& Agree & 65 & 28.6 & 28.6 & 74.4 \\
& Neutral & 15.0 & 15.0 & 89.4 \\
& Disagree & 14 & 6.2 & 6.2 & 95.6 \\
& Strongly disagree & 10 & 4.4 & 4.4 & 100.0 \\
& Total & $\mathbf{2 2 7}$ & $\mathbf{1 0 0 . 0}$ & $\mathbf{1 0 0 . 0}$ & \\
\hline
\end{tabular}

Source: SPSS version 25

Workers join trade unions because of perceived benefits. The idea to join the union remains an individual decision. Table 8 indicates how respondents, view the idea of unions ensuring effective representation in relation to trade union commitment. Of the respondents, 104 (45.8\%) strongly agree, 65 (28.6\%), 34 (15.0\%) were neutral to the view as stated above, $14(6.2 \%)$ disagree and $10(4.4 \%)$ strongly disagree. For the purposes of representation, findings shows that on average $38 \%$ of the respondents agree to the fact that being committed in joining trade unions helps in representation in the event that there is a dispute between the employer and the employee. Shop stewards who are fulltime hotel employees indicate through a focus group discussion that they represented employees in disciplinary hearings. They pointed out that at times mainly on appeals they would invite union officials to represent people. Members appreciated unions more when they see tem representing their interest. The union officials also pointed out that they represented workers through collective bargaining leading to collective bargaining agreements (CBA) uniformly applied across all hotels. Management pointed out that unions were essential in negotiations at times compromising their position for the betterment of the organisations.

This effectively points out to the fact that the ability of union to effectively and successfully represent its members is a ticket to trade union commitment which subsequently leads to trade union revitalisation. Through collective bargaining agreements and strike movements, unions have successfully provided workers with the means to secure better working conditions and improved standards of living as noted by Acayan et al., (2015). This ability to ensure members are effectively represented in all facets of their working life can help enhance member commitment to union business. Where the union fail to represent workers, as individuals at a disaggregated level they see no value of joining let alone committing to the unions (Bergene \& Mamelund, 2017). When members feel the union is weak and cant bargaining effectively member commitment is compromised. Where members feel betrayed by the union commitment is questioned. 
Table 9. To influence work itself

\begin{tabular}{llllll}
\hline & Frequency & Percent & Valid Percent & Cumulative Percent \\
\hline Valid & Strongly agree & 98 & 43.2 & 43.2 & 43.2 \\
& Agree & 65 & 28.6 & 28.6 & 71.8 \\
& Neutral & 18.1 & 18.1 & 89.9 \\
& Disagree & 14 & 6.2 & 6.2 & 96.0 \\
& Strongly disagree & 9 & 4.0 & 4.0 & 100.0 \\
& Total & $\mathbf{2 2 7}$ & $\mathbf{1 0 0 . 0}$ & $\mathbf{1 0 0 . 0}$ & \\
\hline
\end{tabular}

Source: SPSS version 25

Unions play a crucial role in determining the nature of work offered. Findings reveal that the ZCHWU plays a crucial role in setting grades and conditions that apply to such grades. Table 9 shows participants responded when asked to comment if the ability of the union to influence work itself would lead to member commitment. Of the respondents, $98(43.2 \%)$ strongly agree, $65(28.6 \%), 41(18.1 \%)$ were neutral to the view as stated above, $14(6.2 \%)$ disagree and $9(4.0 \%)$ strongly disagree. On average, $36 \%$ of the respondents were in agreement to the view that joining trade unions was for the reason of its ability in influencing work-itself. This can be attributed to the fact that member perception on union influence to their work can act as an antidote to union commitment and revitalisation. Burry and McDaniels (2018) on their reflection of young workers and unions say those higher-skilled young workers, commit to unions when they perceive unions will influence how employers that care about their future, and are able to offer opportunities for meaningful and interesting work with which they can personally identify. Thus the capacity of union to influence work itself is key towards enticing members to join and participate in the union business. This was also pointed out by management that grades are determined at NEC level and the workers committee which represents the interest of the Union enforces this.

\section{Discussion and Summary of Findings}

Generally the findings above depicts that workers are committed to join unions, stay in unions and participate in union business because of the perceived benefits to be obtained. Where a union is able to satisfy both the hygiene and motivators workers will always have a positive perception on the union. Where the union fails to satisfy these it is viewed negatively which may grossly affect the union itself in terms of harnessing commitment. What is important to observe is that member commitment to trade union means commitment to the organisation. That commitment to the union means the union is effective in bargaining for its members. Management can never grant or give in to poor performance which means there is a trade off of good service delivery and any worker demand. Remuneration increases where cash flows are also increasing. Through satisfying union demands that are reasonable unions will ensure their members are giving all their energy to good service quality which can sustain the organisations. We argue that one cannot squeeze water out of a rock. Unions cannot make unreasonable demands. They are part of the management puzzle. When the union is perceived as satisfying member needs, commitment automatically comes along. Anyango, Obange, Ondiek, Odera and Ayugi (2013) point out that the issuance of competitive salaries, distribution fairly of the available resources proper management and supervision are a remedy for revitalisation of trade unions. All these aspects compel the young more as vulnerable workers, women as marginalised and the all those on atypical employment.

The goals of protecting and enhancing employees' living standards motivate workers to join trade unions and stay in the union (Gall \& Fiorito, 2016; Lévesque \& Murray, 2013).currently Zimbabwe is in a serious recession and unions be more collaborative and understanding tan fighting management. Findings above corresponds well with Dufour-Poirier and Laroche (2015) who point out that the ability of unions to properly market themselves, through proper education of the perceived union benefits, training of union workers, opportunities for growth, proper leadership and governance remains key towards membership attraction and trade union revitalisation. Avgar et al., (2018) also weighed in by pointing out that the ability to handle workers concerns, having in place proper grievance handling mechanisms and procedure in place compels employees to participate in trade unionism. This, from the researcher's point of view, is the communication that needs to be taken to union members and potential members to motivate them to commit to trade unions. The impetus for good working conditions and the desire to have a good life in any economic context induce workers to join trade unions (Manky, 2018). Above all unions are and remain the 
vanguard of any business. Through collaborating with management and gain management trust unions survive and negotiate successfully anything for their members. But above all unions enhance and support effective service delivery through encouraging their members so that they enhance their bargaining power.

\section{Conclusion}

Conclusively from the discussion above commitment is a basic underlying measure of the extent to which an individual accepts or identifies with the goals and values of the broader organization, in this instance the trade union understudy. Commitment to an organization thus reflects both attitudes which an individual holds prior to entering an organization and the cumulative effects of experiences with the organization over time. A person's evaluation of the union's ability to obtain certain desired outcomes leads to commitment. These outcomes associated with unions basically include more and better fringe benefits, higher wages, an enforceable grievance procedure and many more as pointed out in the study. Where members have a negative perception when they believe the union's presence is detrimental to the attainment of desired benefits that union grossly affected. Thus for the union to harness commitment it has to be effective. Union effectiveness as consists of union's ability to obtain extrinsic benefits, unions' ability to obtain intrinsic benefits and union's responsiveness to their members. It is imperative that trade unions as voluntary institution convince their members of its worth as a bargaining institution. A positive perception of unions in this regard leads to an enhanced member's commitment. Also union's involvement in employee's quality of work life issues was also found by this study to be a determinant of union commitment. Thus the research recommends that the union to educate members on the members should communicate challenges if any to build confidence. The research also recommends that all collective bargaining agreements are fulfilled to cultivate commitment.

\section{References}

Acayan, A. M., Cua, M. H., \& Te, J. C. (2015). Anteccedents and outcome of Union Commitment. Phillipine Journal of Psychology, 48(1), 59-86.

Alshmemri, M., Shahwari, A. K., \& Maude, F. (2017). Herzberg's Two Factor Theory. Life Science Journal, 12-16. https://doi.org/10.7537/marslsj140517.03

Angrave, D., Charlwood, A., \& Greenwood, I. (2017). Do economic conditions influence union activism behaviour? Economic and Industrial Democracy, 38(2), 344-369. https:// doi.org/10.1177/0143831X15571641

Anyango, C., Obange, N., Abeka, E., Odiek, G. O., Odera, O., \& Ajugi, M. E. (2013). Factors Affecting Perfomance of Trade Unions in Kenya. American Journal of Business and Management, 2(2), 181-185.

Bergene, A. C., \& Mamelund, S. E. (2017). Fit for Fight? A Cross Section study of Union Aparthy in Norway. Economic and Undustrial Democracy, 38(2), 235-265. https:// doi.org/10.1177/0143831X14566889

Bryson, A., \& Freeman, R. B. (2012). Employee Perceptions of Working Comditions and Desire for Worker Representation in Britain and US. Journal of Labour Research, 34(1), 1-29. https://doi.org/10.1007/s12122-012-9152-y

Crounch, C. (2017). Membership Density and Trade Union Power. Transfer, 23(1), 47-61. https://doi.org/10.1177/1024258916673533

Franki, L., \& Hennebert, M. A. (2015). Expressing confidence in Unions in Quebec and other Canadians Provinces. Similarities and Contrasts in findings. Industrial Relations, 70(1), 131-156. https://doi.org/10.7202/1029283ar

Gall, G., \& Fiorito, J. (2016). Union Effectiveness: In search of Holy Grail. Economic and Industrial Democracy, 37(1), $26(1), 561-211$.

Herzberg, F., Mausner, B., \& Snyderman, B. B. (1959). Motivation at Work (2nd Edn). New York: John Willey and Sons.

Kollmeyer, C. J. (2013). Who Joins Trade Unions? Testing New Socilogical Explanations. Comparative Sociology, 12(4), 514-548.

Leschke, J., \& Vandaele, K. (2018). Explaining leaving Union membership by degree of labour market attachment: Exploring the case of Germany Economic and Industrial Democracy. Economic and Industrial Democracy, 39(1), 64-86. https://journals.sagepub.com/doi/full/10.1177/0143831X15603456

Levesque, C., \& Murray, G. (2010). Trade Union cross border Alliances with MNCs: Disentangling Union Dynamics at the Local, National and International Level. Industrial Relations Journal, 14(4), 312-332. https://doi.org/10.1111/j.1468-2338.2010.00571.x 
Manky, O. (2018). Resource Mobilisation and Precarious Worker's Organsation: An Analysis of Chilean Subcontracted Mine Wrkers Union. Work, Employment and Society, 32(3), 181-185.

Okechukwu, U. F. (2016). Trade Union Wage Agitations in Nigeria: The Nigerian Labour Congress. International Journal of Public Administration and Management Research, 3(3), 28-37.

Seeliger, M. (2018). Why do (some) European Trade Unions Reject Minimum Wage Regulation? Trade Union Politics between Intergration and Institutional Nationalism. Culture, Practice and Europeanisation, 3(1), 37-46.

Tripti, S., \& Ginni, C. (2015). Antecedents and Consequencies of Union Participation: A Review. Journal of Advanced Management Science, 3(1), 44-49. https://doi.org/10.12720/joams.3.1.44-49 